DOI https://doi.org/10.18551/rjoas.2020-10.17

\title{
ANALYSIS OF FACTORS AFFECTING THE CRYSTAL GUAVA PRODUCTION STRATEGY
}

\author{
Hasanah Mashlihatul \\ Master's Program of Agribusiness Department, University of Sebelas Maret, \\ Central Java, Indonesia
}

\author{
Harisudin Mohamad, Fajarningsih Rhina Uchyani \\ Faculty of Agribusiness, University of Sebelas Maret, Central Java, Indonesia
}

*E-mail: mashlihatulhasanah@gmail.com

\begin{abstract}
The cultivation technology applied in cultivating crystal guava is still lacking, while the demand for crystal guava continues to increase yet the production has not been able to meet the demand of the consumers. This is the main problem faced by crystal guava farmers. This research focused to farmers in Cikarawang Village, located in Dramaga District, Bogor Regency, is one of the areas for developing crystal guava farming in Indonesia. The purpose of this study was to analyze the factors that influenced the guava crystal production strategy. For data collection in the field, the researcher used in-depth interviews with several key informants. Data were analyzed using Internal Factor Evaluation (IFE), External Factor Evaluation (EFE), and Grand Strategy Matrix. The results of IFE and EFE analysis showed weighted values of 2.97 and 2.88 , which means that crystal guava farming had greater strengths than weaknesses and it had greater opportunities than threats. The results of the Grand Strategy Matrix analysis showed that the value of the $X$ axis $=0.99$ and the $Y$ axis $=$ 0.63 and the coordinate position is in quadrant I (one), which means the perfect position for the company.
\end{abstract}

\section{KEY WORDS}

EFE, IFE, crystal guava, Grand Strategy Matrix.

The increasing number of deaths caused by unhealthy lifestyles results in a high level of public awareness of the importance of changing their lifestyle to be the healthier one. A healthy lifestyle can be started by consuming healthy foods. Meeting nutritional needs in a balanced manner is one of the focuses healthy lifestyle adherents. Many people today understand that the food consumed is not only in the form of heavy food, it must also be balanced with adequate intake of vitamins. Adequate vitamins are obtained from fruits and vegetables. Indonesia has a variety of fruits at affordable prices that have been wellrecognized by its people, such as bananas, guava, apples, papaya, and so on. These typical Indonesian fruits contain high nutrition for health. The position of typical Indonesian fruits is also able to substitute other imported fruits. Apart from the more affordable price, the availability of typical Indonesian fruit is also quite abundant and easy to obtain.

One example of a typical Indonesian fruit which is able to substitute imported fruits is the guava which is known to substitute pears. Crystal guava (Psidium guajava) is an annual fruit plant that is rich in vitamins, minerals as well as other nutrients. It can be consumed directly as fresh fruit without having to be processed first. Crystal guava contains high antioxidants such as phenol and ascorbic acid compounds. Crystal guava was introduced in Indonesia by researchers from Taiwan through the Taiwan Technical Mission in 1998 under the International Cooperation and Development Fund (Taiwan - ICDF) program as a form of Indonesian diplomacy with Taiwan. The inaugural development was carried out in Mojokerto with a positive market response. After finding out that the crystal guava plant had good potential, the Taiwanese government then collaborated with the Bogor Agricultural Institute to create an experimental project on what has now currently become the ICDF Taiwan fruit and 
vegetable garden. Until now, crystal guava has become one of the national superior fruit products. Along with the increasing interest in consuming crystal guava fruit in the community, a balanced increase in production is needed. One of the factors that determine the success in developing crystal guava cultivation is the use of quality seeds of superior varieties.

In the research of Oktaviani, which resulted in a total weight score obtained from the IFE matrix and EFE matrix of 3.16 and 2.46, the result of the SWOT analysis placed PT Sumber Pangan Jaya in quadrant IV, which means a strategy that can be implemented in cell IV is to grow and develop. Whereas in the red chili agribusiness development strategy in Sleman Regency, the result obtained from the grand strategy matrix shows the position in quadrant I (one). This position represents an organization or company with a high market growth and a strong competitive position. The demand for crystal guava is increasing day by day, while the production is still not sufficient for the needs of buyers. The increasing market opportunity for crystal guava demand is very unfortunate if left unchecked. Research with the aim of knowing what factors influence the production of guava crystals is conducted for the first time in Cikarawang Village, Bogor Regency. The purpose of this research is to find out what are the factors that influence the guava crystal production strategy, seen in internal factors and external factors.

\section{METHODS OF RESEARCH}

The basic method used for this research is descriptive analytic method. The location of the research was determined purposively by taking into account the consideration that Gapoktan Mandiri Jaya, located in Cikarawang Village, Dramaga District, Bogor Regency, Indonesia is a farmer group assisted by the Bogor Regency Agricultural Service. In collecting data in the field, the researcher used an in-depth open interview method. The researcher determined key informants as sources of interview information. Determining key informants must go through several considerations which include: the person concerned has personal experience in accordance with the problem being studied, the informant's age is mature, the informant is physically and mentally healthy, the informant is neutral, and the informant has extensive knowledge of the problem under study.

The IFE matrix is intended to identify internal environmental factors and measure the extent of their strengths and weaknesses. In the IFE matrix, the total weighted scores range from $1.0-4.0$ with an average value of 2.5. A value below 2.5 indicates a weak internal condition of the company or region and a value above 2.5 indicates a strong internal position. Total 4.0 shows the company or region is able to use existing strengths to anticipate weaknesses from the total value, 1.0 means that the company or region is unable to anticipate weaknesses by using its strengths.

The EFE matrix is intended to identify external environmental factors and measure the extent of opportunities and threats faced by the region. In the IFE matrix, the total weighted score ranges from 0 - 1.0 on each external factor. It provides a rating of 1 to 4 for each factor to indicate whether it is very weak (rank 1), weak (rank 2), strong (rank 3 ), and very strong (rank 4). In the EFE matrix, the highest total weighted score is 4.0 which indicate that the company or region is able to respond to existing opportunities and avoid threats in the industrial market. The lowest value is 1.0 , which indicates the strategy carried out by the company or region cannot take advantage of opportunities or does not avoid existing threats.

The grand strategy matrix is based on two evaluative dimensions: competitive position and market growth (industry). Also suggests that the strategies an organization is able to consider are arranged in the order of their attractiveness in each matrix quadrant. Based on the analytical framework of strategy formulation, the grand strategy matrix is a matching stage such as the BCG matrix, IE matrix and SPACE or SWOT matrix. In the grand strategy matrix, each of these companies will be entered into 4 different quadrants according to their level. The grand strategy matrix is based on two evaluative dimensions; competitive position and market growth (industry). Any industry whose annual sales growth exceeds $5 \%$ can be 
considered as having rapid growth. The right strategy to consider, the organization is displayed in order of attractiveness in each quadrant of the matrix.

RAPID MARKET GROWTH

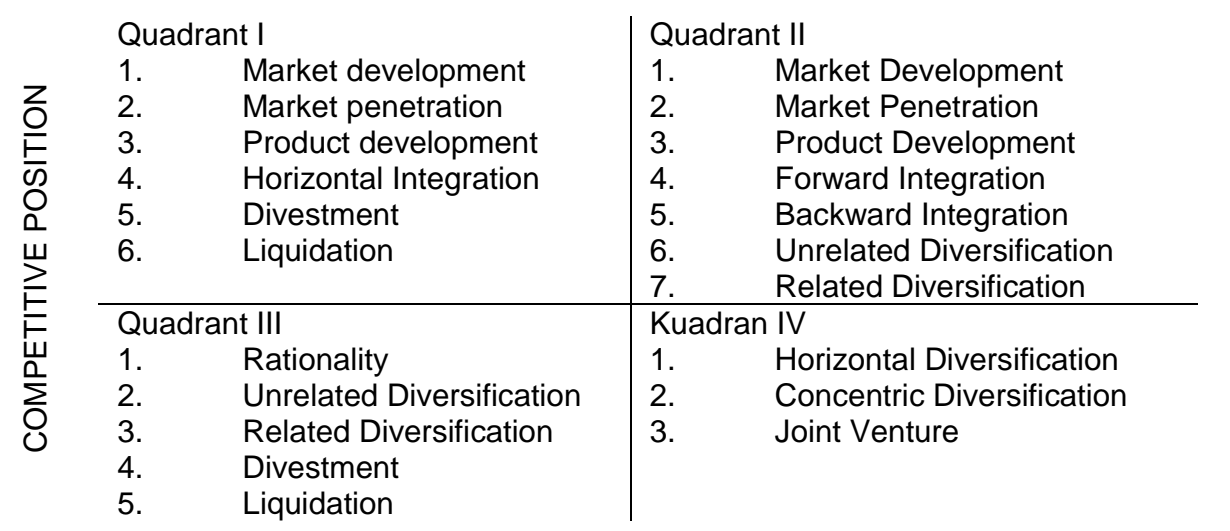

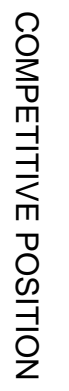

\section{SLOW MARKET GROWTH}

Figure 1 - "Grand Matrix Strategy (David, 2009)"

\section{RESULTS AND DISCUSSION}

Internal factors include strengths and weaknesses that can affect the quadrant position of the crystal guava production strategy.

The strength factors are parts of the internal strategic factor, this factor is a strength that will affect the guava crystal production strategy. The factors which become strengths must be used as much as possible in an effort to achieve the goal of the crystal guava production strategy. These factors consist of (1) the production facilities are easily obtained; (2) there have been regular buyers; (3) Government's guidance is quite intensive; (4) regularly participating in exhibitions held by the government; (5) there is no price competition among farmers; (6) consumers' trust in product quality is quite high; and (7) buyers are willing to buy products without grading.

Based on the observation done in the field, it was found that there were 2 factors that had the highest points from the IFE analysis on the element of strengths, including:

The production facilities are easily obtained. This is the main input in the process of crystal guava cultivation, especially fertilizer. Fertilization is any effort which aims to increase the availability of nutrient elements needed by plants, increase crop production and quality. To increase the production and quality of crystal guava fruit, it is necessary to fertilize them with micro fertilizers. Micro fertilizers, especially those containing zinc $(\mathrm{Zn})$ and copper $(\mathrm{Cu})$, are very important to be given to crystal guava, papaya, banana, grapes, and various other tropical and subtropical fruits to improve fruit quality, extend shelf life and reduce damage during storage.

The application of nutrient fertilizer (phosphorus) can increase plant height and stem diameter, while combination of nitrogen, phosphorus and potassium which commonly called as compound fertilizer can increase the number of leaves, chlorophyll, number of finished flowers, and number of fruits on crystal guava plants. The application of compound fertilizer at a dose of $20 \mathrm{~g} /$ plant can enhance the increase in the amount of chlorophyll, the number of finished flowers, the number of flowers and the number of fruits in crystal guava plants. This compound fertilizer with a dose of $20 \mathrm{~g} /$ plant can increase the growth and yield of crystal guava plants.

$60 \%$ of global food production results from the use of suitable fertilizers. It can be said that the calculation and application of fertilizers according to the dosage is very important in the cultivation of crystal guava plants. The cost of fertilization, irrigation, and labor required can affect the amount of production costs incurred for the cultivation of crystal guava. Plants 
fertilized with macro and micro nutrients are able to increase the metabolic process, thereby increasing the production and quality of the fruit produced.

Farmers in Cikarawang Village have easy access to production facilities for crystal guava cultivation. Farmers can obtain production facilities from Gapoktan Mandiri Jaya and the nearest agricultural shop. The government also supports the provision of production facilities to farmers and farmer groups, so that the availability of production facilities becomes a strength for the development of crystal guava agribusiness.

Consumers' trust in product quality is quite high. Trust has an important role for consumers to make a decision on the purchase of a desired product. At first, consumers cannot recognize the characteristics of a safe product directly, so consumers must trust stakeholders (farmers, traders and government). Building a trust is not easy, but over time, both farmers, traders and the government are able to foster a sense of trust in consumers towards the quality of crystal guava cultivated in Cikarawang Village.

The growing sense of trust can have an impact on the purchase price of crystal guava that is neither too low nor too high during the harvest season. Focusing on maintaining product quality will be able to increase trust in consumers, so that consumers can become regular customers for purchasing crystal guava.

Table 1 - IFE Matrix Analysis Results (Internal Focus Evaluation)

\begin{tabular}{|c|c|c|c|c|}
\hline No & Internal Factors & Average weight & Average Rating & Weighted Value \\
\hline \multicolumn{5}{|c|}{ Strength } \\
\hline 1 & Production facilities are easily obtained & 0.09 & 4 & 0.34 \\
\hline 2 & There have been regular buyers & 0.08 & 4 & 0.34 \\
\hline 3 & Government's guidance is quite intensive & 0.08 & 4 & 0.31 \\
\hline 4 & Regularly participating in exhibitions held by the government & 0.07 & 3 & 0.21 \\
\hline 5 & There is no price competition among farmers & 0.07 & 3 & 0.22 \\
\hline 6 & Consumers' trust in product quality is quite high & 0.09 & 4 & 0.36 \\
\hline 7 & Buyers are willing to buy products without grading. & 0.07 & 3 & 0.20 \\
\hline Tot & & & & 1.98 \\
\hline \multicolumn{5}{|c|}{ Weakness } \\
\hline 1 & The application of cultivation technology by farmers is still weak & 0.07 & 2 & 0.14 \\
\hline 2 & The continuity of production is still not guaranteed & 0.07 & 2 & 0.14 \\
\hline 3 & Administration access to capital is still impeded & 0.07 & 1 & 0.07 \\
\hline 4 & The number of human resources is decreasing & 0.07 & 2 & 0.14 \\
\hline 5 & There is no marketing for other processed guava products & 0.06 & 2 & 0.13 \\
\hline 6 & There are still farmer institutions that are less active & 0.07 & 2 & 0.14 \\
\hline 7 & Group members have other activities to do & 0.07 & 1 & 0.07 \\
\hline 8 & Promotion for processed crystal guava products & 0.08 & 2 & 0.16 \\
\hline \multicolumn{3}{|c|}{ Total } & & 0.99 \\
\hline \multicolumn{4}{|c|}{ Total in Internal Factors } & 2.97 \\
\hline
\end{tabular}

Source: Primary Data Analysis, 2020.

Weakness factors are part of internal strategic factors, these factors will affect the production of crystal guava. Factors that become weaknesses must be considered carefully to reduce risks and achieve the goal of crystal guava farming production. These factors include (1) the application of cultivation technology by farmers is still weak; (2) the continuity of production is not guaranteed; (3) access to capital is still impeded by administration; (4) decreasing number of human resources; (5) there is no marketing for other processed guava products; (6) there are still less active farmer institutions; (7) group members have other activities; and (8) promotion of processed crystal guava products.

Based on the observation done in the field, it was found that there was one factor that had the highest points from the IFE analysis on the element of weakness.

The Female Farmers Group (FFG) is a member of Gapoktan Mandiri Jaya, which is active in processing derivative products from crystal guava and food crop plants, which are the focus of Gapoktan Mandiri Jaya. FFG is responsible for starting from the post-harvest process to becoming a finished product as well as marketing the finished product. Especially for crystal guava plants, FFG has not done the marketing perfectly. The absence of a registration permit from the Food and Drug Administraton (FDA) and the lack of promotion are the weaknesses of a crystal guava derivative product in Cikarawang Village. 
Promoting a superior product from each region and expanding the market through the use of information and communication technology is something that can be done. Crystal guava has high nutritional value, which can be consumed fresh or processed into candy, juice, and jelly. This is for the sake that the guava crystal derivative products can have additional value.

Based on the analysis of the external environment, it is found that external strategic factors become opportunities and threats that affect the crystal guava production strategy in Cikarawang Village, Bogor Regency.

The factors which become opportunities involve (1) high market demand for crystal guava; (2) climate and soil suitable for cultivation; (3) the existence of technology which helps in cultivation; (4) government support from various sectors; and (5) a location close to the IPB campus, making it easier to access to get support from researchers and students.

Based on the observation done in the field, it was found that there is one factor that had the highest points from the EFE analysis on the element of opportunity, namely:

Market demand for high crystal guava. Crystal guava is a fruit rich in vitamins. Field observations show that the demand for crystal guava is high, both in local markets and nonlocal markets (outside the region). The high demand for crystal guava commodity is an opportunity for farmers and the local government to continue improving the cultivation of crystal guava, in order to increase farmers' income and be able to participate in increasing crystal guava production.

Table 2 - EFE Matrix Analysis Results (External Focus Evaluation)

\begin{tabular}{|c|c|c|c|c|}
\hline No & External Factors & $\begin{array}{l}\text { Average } \\
\text { weight }\end{array}$ & $\begin{array}{l}\text { Average } \\
\text { rating }\end{array}$ & $\begin{array}{l}\text { Weighted } \\
\text { value }\end{array}$ \\
\hline \multicolumn{5}{|c|}{ Opportunities } \\
\hline 1 & Market demand for high crystal guava & 0.12 & 4 & 0.47 \\
\hline 2 & Climate and soil suitable for cultivation & 0.11 & 3 & 0.33 \\
\hline 3 & The existence of technology that helps in cultivation & 0.12 & 4 & 0.46 \\
\hline 4 & \multirow{2}{*}{$\begin{array}{l}\text { Government support from various sectors } \\
\text { The location is close to university so that it makes it easy to get support } \\
\text { from researchers and students }\end{array}$} & 0.10 & 3 & 0.31 \\
\hline 5 & & 0.09 & 2 & 0.18 \\
\hline Total & & & & 1.76 \\
\hline \multicolumn{5}{|c|}{ Threats } \\
\hline 1 & Competition of land with other agricultural commodities & 0.10 & 3 & 0.29 \\
\hline 2 & Plant pests attacks & 0.10 & 3 & 0.31 \\
\hline 3 & Competition with other regions & 0.10 & 2 & 0.19 \\
\hline 4 & Marketing of processed products is not guaranteed & 0.08 & 2 & 0.17 \\
\hline 5 & High rainfall & 0.08 & 2 & 0.16 \\
\hline \multicolumn{2}{|c|}{ Total } & & & 1.13 \\
\hline \multicolumn{3}{|c|}{ Total in External Factors } & & 2.88 \\
\hline
\end{tabular}

Source: Primary Data Analysis, 2020.

The existence of technology which helps in cultivation. Crystal guava cultivation technology in accordance with Good Agricultural Practices (GAP) is an important factor in producing significant crystal guava production. Good Agricultural Practices (GAP) is a guideline for implementing good and correct cultivation in the agricultural sector. In general, the application of GAP cannot be said in full for each commodity, so the application can only be said to be the application of intensive cultivation such as fertilization, pruning, maintenance, and control of plant pests. Storage time can affect the physical and chemical properties of the fruit, the total value of dissolved solids in crystal guava fruit increases with storage time.

Wrapping is a technology that can be applied to crystal guava cultivation. Fruit wrapping is carried out while the fruit is still on the tree to prevent damage to the fruit which can affect the quality of the fruit. The wrapping can also speed up the fruit harvest period, this is because the temperature inside the shell is hotter, especially in the plastic type shell compared to the paper type. One of the advantages of using plastic type cartridges is that they are not easily damaged and are waterproof.

Horticultural product quality parameters can be evaluated by measuring the physical quality (appearance and texture) and chemical quality (taste and nutritional value). 
Appearance can be evaluated based on fruit size, shape, color, luster and external / internal defects. The treatment of the active ingredients of chlorpyrifos, abamectin, and mankozeb pesticides has a very significant effect on reducing the level of defects in fruit by twofold.

According to [25] improving the quality of guava fruit is carried out to produce fruit that has a similar shape, good size, and attractive fruit color. The growth, yield and quality of guava fruit for commercial production can be controlled easily with horticultural practices such as pruning techniques and limiting the amount per fruit per plant for good yields, depending on the situation.

The factors which become threats include (1) competition between land and other agricultural commodities; (2) attack by plant pests; (3) competition with other regions; (4) marketing of processed products is not guaranteed; and (5) high rainfall.

Based on the observation done in the field, it was found that there is one factor that has the highest points from the EFE analysis on the threat element, namely:

Attack by plant pests. The effect of attacks from plant pests on the amount of crystal guava production is a threat to farmers in Cikarawang Village. According to farmers, when the rainy season has arrived, various plant pests will attack the area of crystal guava farming. Fruit flies (Bactrocera sp.) are a group of insect pests that are important pests on several fruits and vegetables, and even become the main plant pests. Larvae of Bactrocera sp. damages the fruit of the host plant and causes the fruit to rot faster. Characteristics of fruit affected by Bactrocera sp. is there are small stains brown to blackish. Fruit infected with Bactrocera sp. will fall before maturity and will become the host source for Bactrocera sp. the next generation. Rotten and decayed fruit should be quickly thrown away and not left unattended on cashew crystal land. One of the successful and successful fruit fly control efforts is the use of an attractant, methyl eugonal + trap.

The disease that often attacks the crystal guava plant is anthracnose. Pathogens that cause anthracnose can attack all parts of the plant, especially in the fruit. Symptoms include spots on the fruit, so that the fruit rot quickly and the young leaves curl at the ends. The pests attack almost evenly occurred in all guava crystal land, so that it can cause the yield of crystal guava to shrink.

Stage 1 of the formulation framework consists of the IFE and EFE Matrix (Tables 1 and 2 ), then in stage 2, the matching stage focuses on creating alternative strategies that make sense by taking into account the main internal and external factors. In this research, the matching stage uses the Grand Strategy Matrix analysis.

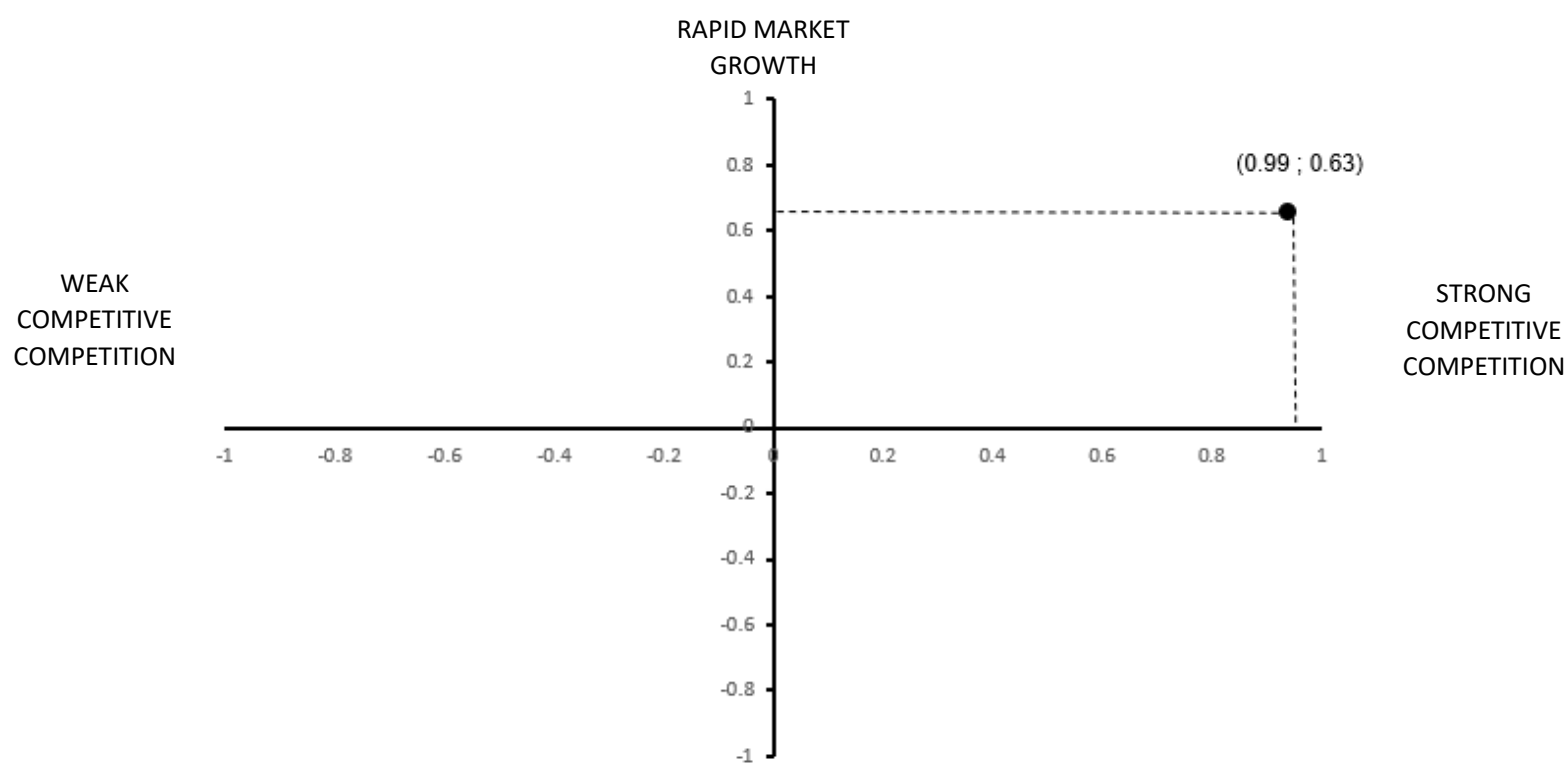

Figure 2 - Grand Strategy Quadrant Position 
The results of the calculation of each factor, namely internal factors and external factors, are used to determine the coordinates of the development strategy that can be carried out. The horizontal $(X)$ axis is an internal factor, where the value of the $X$ coordinate is the difference between the strength factor minus the weakness factor, namely (1.98-0.99) $=0.99$. The vertical $(Y)$ axis is an external factor, where the $Y$ coordinate value is the difference between the opportunity factor minus the threat factor, namely $(1.76-1.13)=0.63$.

The results obtained from the Grand Strategy matrix show the position of the coordinates in quadrant I (one). This position represents an organization or company with a high market growth and a strong competitive position. In this position, the guava crystal farming in Cikarawang Village has greater strengths than weaknesses and as well as greater opportunities than threats. Companies that are in quadrant I (one) in the Grand Strategy matrix have a perfect strategic position. For these companies, the current concentration on the market (market penetration and market development) and product (product development) is an appropriate strategy. Market penetration that can be done is to strengthen the network in the existing market by maintaining and improving the quality of crystal guava. Market development can be done by selling crops not only on the island of Java. Product development by converting crystal guava fruit into processed products such as candies, juice, and jelly adds values.

\section{CONCLUSION}

The results showed the IFE matrix analysis, the strength factor was 1.98 and the weakness factor was 0.99 . Consumers have a high sense of trust in crystal guava which is the main factor in the IFE matrix analysis (strength factor). This needs to be maintained and improved to avoid consumers' disappointment in the future with the quality of crystal guava fruit. The lack of promotion, especially in crystal guava, is a major factor in the IFE matrix analysis (weakness factor). FFG, which is responsible for marketing crystal guava products, should focus more and make new innovations on guava, such as making candy from crystal guava.

The high market demand for crystal guava is a major factor in the EFE matrix analysis (opportunity factor). This needs to be improved in order to maintain the quality of crystal guava and increase farmers' income. The attack of plant pests is a major factor in the EFE matrix analysis (threat factors). Traditional prevention can be done by wrapping the fruit in cement paper, so that the fruit is safe from pest attack and production does not shrink.

While the coordinate position in the grand strategy matrix is in quadrant I (one), which means that this position represents an organization or company with high market growth and a strong competitive position. Concentrating on markets such as market penetration and market development as well as product development from crystal guava.

\section{REFERENCES}

1. Mahendra, I. G. J., Rai, I. N., \& Wiraatmaja, I. W. (2017). Upaya Meningkatkan Produksi dan Kualitas Buah Jambu Biji Kristal (Psidium guajava L. cv. Kristal) Melalui Pemupukan. Agrotrop, 7(1), 60-68.

2. Oktaviani, D., Wastra, A. R., \& Dwiningsih, E. (2019). Strategi Pengembangan Bisnis Produk Olahan Daging Di Pt. Sumber Pangan Jaya Cikarang - Jawa Barat. Agribusiness Journal, 12(1), 27-31. https://doi.org/10.15408/aj.v12i1.11848

3. Lubis, F. A., Mohamad, H., \& Rhina, U. F. (2019). Development Strategy of Red Chili. Agraris: Journal of Agribusiness and Rural Development Research, 5(2), 119-128. https://doi.org/http://dx.doi.org/10.18196/agr.5281

4. Bungin, B. 2007. Penelitian Kualitatif: Komunikasi, Ekonomi, Kebijakan Publik dan IImu Sosial lainnya. Putra Grafika. Jakarta (ID).

5. David, F. R. (2009). Manajemen Strategis Konsep. Edisi Ke-12. Salemba Empat.Jakarta (ID).

6. Kurniawati, T., \& B, D. K. S. K. (2009). Analisis dan Pilihan Strategi: Membangun 
Esksistensi Perusahaan di Masa Krisis. Jurnal Ekonomi Bisnis, 179-190.

7. Zaroni \& Pujiati. (2019). Strategi Pengembangan Usahatani Jambu Biji Getas Merah. Economic Education Analysis Journal. 2(1), 1147-1162. https://doi.org/10.15294/eeaj.v13i2.35710

8. Fiana, Y., Dhyani N. P., M. R. (2015). Kajian teknologi pemupukan terhadap pertumbuhan vegetatif tanaman jeruk keprok Borneo Prima di Kabupaten Bulungan, Kalimantan Utara. Pros Sem Nas Masy Biodiv Indon, 1(4), 319-323. https://doi.org/10.13057/psnmbi/m010225

9. Mandal, G., Dhaliwal, H. S., \& Mahajan, B. V. C. (2012). Effect of pre-harvest application of NAA and potassium nitrate on storage quality of winter guava (Psidium guajava). Indian Journal of Agricultural Sciences, 82(11), 985-989.

10. Yadav, M . K \& Solanki, V. K. (2015). Use of micronutrients in tropical and subtropical fruit crops: A review. African Journal of Agricultural Research, 10(5), 416422. https://doi.org/10.5897/ajar2014.9287

11. Tini, E. W., Rahman, A. K., \& Mugiastuti, E. (2019). Pemanfaatan Macam dan Dosis Pupuk untuk Meningkatkan Pertumbuhan dan Hasil Jambu Biji Kristal (Psidium guajava). Agrotechnology Research Journal, 3(1), 36. https://doi.org/10.20961/agrotechresj.v3i1.30408

12. Roberts, T. L. (2009). The role of fertilizer in growing the world's food. Better Crops, 93(2), 12-15.

13. Natale, W., Rozane, D. E., de Medeiros Corrêa, M. C., Parent, L. E., \& de Deus, J. A. L. (2020). Diagnosis and management of nutrient constraints in guava. Fruit Crops, 711-722. https://doi.org/10.1016/b978-0-12-818732-6.00048-4

14. Hobbs, J., \& Goddard, E. (2015). Consumers and trust. Food Policy, 52. https://doi.org/10.1016/j.foodpol.2014.10.017

15. Lassoued, R., \& Hobbs, J. E. (2015). Consumer confidence in credence attributes: The role of brand trust. Food Policy, 52, 99-107. https://doi.org/10.1016/j.foodpol.2014.12.003

16. Lassoued, Rim, \& Hobbs, J. E. (2014). The Determinants of Consumer Confidence in Credence Attributes: Trust in the Food System and in Brands. 2014 AAEA/EAAE/CAES Joint Symposium, Social Networks, Social Media and the Economics of Food, (5), 29-30.

17. Lobb, A. E., Mazzocchi, M., \& Traill, W. B. (2007). Modelling risk perception and trust in food safety information within the theory of planned behaviour. Food Quality and Preference, 18(2), 384-395. https://doi.org/10.1016/j.foodqual.2006.04.004

18. Ngo, H. M., Liu, R., Moritaka, M., \& Fukuda, S. (2020). Urban consumer trust in safe vegetables in Vietnam: The role of brand trust and the impact of consumer worry about vegetable safety. Food Control, 108(8), 106-856. https://doi.org/10.1016/j.foodcont.2019.106856

19. Darmansyah, A., Rochana, S. H., Sutardi, A., \& Zuraida, U. (2014). The New Growth Centres and Strategy for Building and Accelerating Agribusiness Development in Cirebon Regency, Indonesia. Procedia - Social and Behavioral Sciences, 115(2013), 296-304. https://doi.org/10.1016/j.sbspro.2014.02.437

20. Kadek, N. I., Sustia, E. M. A., \& Wijana, G. (2017). Kajian Fisikokimia selama Penyimpanan Buah Jambu Biji ( Psidium guajava L .) Varietas Kristal pada Perbedaan Teknik Budidaya dan Tingkat Kematangan Buah The Phycochemical Study of Kristal Guava ( Psidium guajava L .) During Storage under Difference Cultiv. JURNAL AGROTOP, 7(2), 147-156.

21. Dhyan, C., Sumarlan, S. H., \& Susilo, B. (2014). The influence of bee wax coating and storage temperature on guava 's quality (Psidium guajava $L$.). Jurnal Bioproses Komoditas Tropis, 2(1), 79-90.

22. Dhyan, C., Sumarlan, S. H., \& Susilo, B. (2014). The influence of bee wax coating and storage temperature on guava 's quality (Psidium guajava $L$.). Jurnal Bioproses Komoditas Tropis, 2(1), 79-90.

23. Rustani dan Slamet. (2013). Kualitas Fisik dan Kimia Buah Jambu 'Kristal' pada 
Letak Cabang yang Berbeda Physical and Chemical Quality of 'Crystal' Guava on Different Branch Position Dona. Journal of Chemical Information and Modeling, 53(9), 1689-1699. https://doi.org/10.1017/CBO9781107415324.004

24. Parameswara, Y. S., \& Susanto, S. (2019). Perbaikan Teknik Pembrongsongan melalui Aplikasi Pestisida untuk Meningkatkan Kemulusan Buah Jambu Kristal $\begin{array}{llll}\text { (Psidium guajava L). Buletin Agrohorti, } & \text { 7(1), } 62 .\end{array}$ https://doi.org/10.29244/agrob.7.1.62-68

25. Nimisha, S., Kherwar, D., Ajay, K. M., Singh, B., \& Usha, K. (2013). Molecular breeding to improve guava (Psidium guajava L.): Current status and future prospective. Scientia Horticulturae, 164, 578-588. https://doi.org/10.1016/j.scienta.2013.10.017

26. Lakpathi, G., Rajkumar, M. and Chandrasekhar, R. (2013). Effect of pruning intensities and fruit load on growth, yield and quality of Guava (Psidium guajava L.) CV. Allahabad safeda under high density planting. International Journal of Current Research, 7(2002), 1853-1860.

27. Sahetapy, B., Uluputty, M. R., \& Naibu, L. (2019). Identifikasi Lalat Buah (Bactrocera spp), pada Tanaman Cabai (Capsicum Annum L.) dan Belimbing (Averrhoa carambola L.) dikecamatan Salahutu kabupaten Maluku Tengah. Agrikultura, 30(2), 63. https://doi.org/10.24198/agrikultura.v30i2.23659

28. Lengkong, M., Rante, C. S., \& Meray, M. (2011). Aplikasi MAT dalam Pengendalian Lalat Buah Bactrocera sp . Pada Tanaman Cabe. Eugenia, 17(2), 121-128. 